\title{
The 100 most-cited articles on pectus deformities: A bibliometric analysis
}

\author{
Pektus deformitelerine ilişkin en çok atıf alan 100 makale: Bibliyometrik bir analiz \\ Hüseyin Yıldıran $@$, Güven Sadi Sunam $(\mathbb{D}$ \\ Department of Thoracic Surgery, Selçuk University Medical School, Konya, Turkey
}

\begin{abstract}
Background: In this study, we aimed to examine the development of knowledge on pectus deformities through a meticulous analysis of the 100 most-cited articles published on this topic.

Methods: Publications related to pectus deformities from January 1975 to April 2020 were scanned using the Web of Science Core Collection database. The publications were ranked from maximum to minimum according to the number of citations and were examined in detail.
\end{abstract}

Results: The 100 articles were published in 27 different journals and received a total of 8,290 citations. The average of the impact factors of journals in 2018 was 4.441 . The mean citation density of all articles was $5.1 \pm 3$.8. In the past years, a surgical technique definition and experience transfer were more frequently used, while complications and technical details were started to be presented in recent years.

Conclusion: Our study results suggest that the studies of pectus deformities would continue and, from now on, issues such as complications and technical details would come to the forefront in the articles.

Keywords: Bibliometrics, citation, pectus deformities, surgery.

Repair surgeries of pectus deformities have continually advanced and become an important area of research interest due to their serious aesthetic issues and functional limitations. Many leading surgeons have described techniques and shared their experiences throughout the history. The first publication concerning pectus excavatum in the literature belongs to Bauhinus and Schenck von
$\ddot{O} Z$

Amaç: Bu çalışmada, pektus deformitelerine ilişkin bilgi hafızasının gelişimi, konu üzerine yayımlanmış ve en çok atıf alan 100 makale titizlikle incelenerek araştırıldı.

Çalışma planı: Ocak 1975 - Nisan 2020 tarihleri arasında, Web of Science Core Collection veri tabanında pektus deformitelerine ilişkin yayınlar tarandı. Yayınlar atıf sayısına göre çoktan aza doğru sıralandı ve detaylı olarak incelendi.

Bulgular: İncelenen 100 makalenin 27 farklı dergide yayımlandığ1 ve toplam 8.290 atıf aldığı gözlendi. Dergilerin 2018 yılında etki faktörlerinin ortalaması 4.441 idi. Tüm yayınların ortalama atıf yoğunluğu $5.1 \pm 3.8$ idi. Geçmiş yıllarda cerrahi bir teknik tanımlama ve deneyim aktarımına daha çok yer verilir iken, son y1llarda komplikasyonlar ve teknik detayların sunulmaya başlandığı gözlendi.

Sonuç: Çalışma sonuçlarımız, pektus deformitelerine ait çalışmaların devam edeceğini ve bundan sonra komplikasyon ve teknik detay gibi konuların makalelerde ön plana çıkacağını düşündürmektedir.

Anahtar sözcükler: Bibliyometri, atıf, pektus deformiteleri, cerrahi.

Grafenberg, ${ }^{[1]}$ who described the case of a male patient in 1594; however, the first surgical intervention, a costal cartilage excision, was reported by Meyer in $1911 .^{[2]}$ To date, many articles have been written, many techniques have been defined, and experiences with these techniques have been shared frequently on pectus deformities, dating back to the early $20^{\text {th }}$ century in the field of surgery. 
Bibliometric analyses are the studies which best show knowledge memory in a research area. In many areas, bibliometric analyses have been conducted, and the number of citations and articles has been shown to be useful in a particular area. In addition to general areas such as cardiac surgery and general thoracic surgery, bibliometric studies have been conducted on subspecialty issues, such as burns and rheumatoid arthritis. $^{[3-6]}$

In the present study, we aimed to examine the development of knowledge on pectus deformities through a meticulous analysis of the 100 most-cited articles published on this topic.

\section{MATERIALS AND METHODS}

Publications related to pectus deformities from January 1975 to April 2020 were scanned in the Web of Science Core Collection database. The key terms "chest wall" OR "pectus deformit*" OR "pectus carinatum" OR "pectus excavatum" were searched, and duplicate publications were excluded. The publications were ranked from maximum to minimum according to the number of citations, full-texts of the first 100 publications were obtained, and the publications were examined in detail. Articles that dealt with subjects other than pectus deformity or the main subject of another study, such as breast cancer, chest wall tumors, and Marfan syndrome were excluded from the study.

The names of the journals, number of citations, year of publication, citation density (citation number/time since publication), principal author and country, type of article and subject were examined for the 100 most-cited articles. The impact factors of journals in 2018 were examined.

Since this study is a bibliometric analysis and publicly available information was compiled, ethical approval was waived.

\section{Statistical analysis}

Statistical analysis was performed using the IBM SPSS version 25.0 software (IBM Corp., Armonk, NY, USA). The suitability of the data to normal distribution was checked using the Shapiro-WilkFrancia test. The Spearman's rho test was used to examine the correlations among variables. A $p$ value of $<0.05$ was considered statistically significant with $95 \%$ confidence interval (CI).

\section{RESULTS}

\section{General bibliometric results}

Top-100 most-cited articles regarding pectus deformities were determined in order of the number of citations (Table 1). The articles were published in 27 different journals and received a total of 8.290 citations (min 43 - $\max$ 638). According to the addresses of their first authors, they were written by 69 authors from 21 countries. There were 29 articles whose average number of citations surpassed 82.9.

"A 10-year review of a minimally invasive technique for the correction of pectus excavatum" published in the Journal of Pediatric Surgery in 1998 was the article having the highest total number -638 citations- and also registered the highest number of citations per year with 29.

\section{Journals and impact factors}

Of the 100 articles with the highest number of citations, the journal that published the most articles on pectus deformities was the Journal of Pediatric Surgery. While there were 36 publications in this journal, the total number of citations was 3.362. This number of citations constituted $40.5 \%$ of all citations received by the articles in the first 100 rankings. This was followed by the Annals of Thoracic Surgery (10 articles), which published the second most articles in the top 100 citation rankings about pectus deformities. The total number of citations in this journal was 698. The journal with the highest number of citations per article was the Journal of Bone and Joint Surgery- American Volume with an average of 177.6 citations.

The mean of the impact factors of the 27 journals with articles among the 100 most-cited in 2018 was 4.441 (1.062-16.494) (Table 2).

\section{Citation density and years of publication}

All articles were published between 1980 and 2013 , and the mean citation density of all articles was $5.1 \pm 3.8$ ( $\min 1.2-\max 29$ ). There were 33 articles above this average, and the citation density of the other 67 articles was below the mean density.

The article, with the highest citation density $(n=29)$, was also the article with the highest number of citations: "A 10-year review of a minimally invasive technique for the correction of pectus excavatum". ${ }^{[7]}$ This was followed by the third and seventh most-cited articles "The characteristics of thoracic insufficiency syndrome associated with fused ribs and congenital scoliosis" and "Twenty-One Years of Experience With Minimally Invasive Repair of Pectus Excavatum by the Nuss Procedure in 1,215 Patients" which had the second and third highest citation densities-16.88 and 16.3, respectively. ${ }^{[8,9]}$ 


\section{Table 1. Rankings of $\mathbf{1 0 0}$ most-cited articles}

\begin{tabular}{|c|c|c|c|c|}
\hline Rank & Articles & Country & $\begin{array}{l}\text { Number of } \\
\text { citation }\end{array}$ & $\begin{array}{l}\text { Citation } \\
\text { density }\end{array}$ \\
\hline 1 & $\begin{array}{l}\text { Nuss D, et al. A 10-year review of a minimally invasive technique for the correction of pectus } \\
\text { excavatum. J Pediatr Surg 1998;33(4):545-552. }\end{array}$ & USA & 638 & 29 \\
\hline 2 & $\begin{array}{l}\text { Haller JA, et al. Use of CT scans in selection of patients for pectus excavatum surgery: a } \\
\text { preliminary report. J Pediatr Surg 1987;22(10):904-906. }\end{array}$ & USA & 319 & 9.66 \\
\hline 3 & $\begin{array}{l}\text { Campbell Jr RM, et al. The characteristics of thoracic insufficiency syndrome associated with } \\
\text { fused ribs and congenital scoliosis. JBJS 2003;85(3):399-408. }\end{array}$ & USA & 287 & 16.88 \\
\hline 4 & $\begin{array}{l}\text { Campbell Jr RM, et al. The effect of opening wedge thoracostomy on thoracic insufficiency } \\
\text { syndrome associated with fused ribs and congenital scoliosis. JBJS 2004;86(8):1659-1674. }\end{array}$ & USA & 201 & 12.56 \\
\hline 5 & $\begin{array}{l}\text { Croitoru DP, et al. Experience and modification update for the minimally invasive Nuss technique } \\
\text { for pectus excavatum repair in } 303 \text { patients. J Pediatr Surg 2002;37(3):437-445. }\end{array}$ & USA & 199 & 11.05 \\
\hline 6 & $\begin{array}{l}\text { Hebra A, et al. Outcome analysis of minimally invasive repair of pectus excavatum: review of } 251 \\
\text { cases. J Pediatr Surg 2000;35(2):252-258. }\end{array}$ & USA & 179 & 8.95 \\
\hline 7 & $\begin{array}{l}\text { Kelly RE, et al. Twenty-one years of experience with minimally invasive repair of pectus excavatum } \\
\text { by the Nuss procedure in } 1215 \text { patients. Ann Surg 2010;252(6):1072-1081. }\end{array}$ & USA & 163 & 16.30 \\
\hline 8 & $\begin{array}{l}\text { Molik KA, et al. Pectus excavatum repair: experience with standard and minimal invasive } \\
\text { techniques. J Pediatr Surg 2001;36(2): 324-328. }\end{array}$ & USA & 149 & 7.84 \\
\hline 9 & $\begin{array}{l}\text { Park HJ, et al. The Nuss procedure for pectus excavatum: evolution of techniques and early results } \\
\text { on } 322 \text { patients. Ann Thorac Surg 2004;77(1):289-295. }\end{array}$ & $\begin{array}{l}\text { South } \\
\text { Korea }\end{array}$ & 146 & 9.12 \\
\hline 10 & $\begin{array}{l}\text { Emans JB, et al. The treatment of spine and chest wall deformities with fused ribs by expansion } \\
\text { thoracostomy and insertion of vertical expandable prosthetic titanium rib: growth of thoracic } \\
\text { spine and improvement of lung volumes. Spine } 2005 ; 30(17 \mathrm{~S}): 58-68 \text {. }\end{array}$ & USA & 141 & 9.40 \\
\hline 11 & $\begin{array}{l}\text { Haller Jr JA, et al. Chest wall constriction after too extensive and too early operations for pectus } \\
\text { excavatum. Ann Thorac Surg 1996;61(6):1618-1625. }\end{array}$ & USA & 125 & 5.20 \\
\hline 12 & $\begin{array}{l}\text { Park HJ, et al. Complications associated with the Nuss procedure: analysis of risk factors and } \\
\text { suggested measures for prevention of complications. J Pediatr Surg 2004;39(3):391-395. }\end{array}$ & $\begin{array}{l}\text { South } \\
\text { Korea }\end{array}$ & 124 & 7.75 \\
\hline 13 & $\begin{array}{l}\text { Nuss D, et al. Review and discussion of the complications of minimally invasive pectus excavatum } \\
\text { repair. Eur J Pediatr Surg 2002;12(04):230-234. }\end{array}$ & USA & 121 & 6.72 \\
\hline 14 & Iseman MD, et al. Pectus excavatum and scoliosis. Am Rev Respir Dis 1991;144(914-916):11. & USA & 111 & 3.82 \\
\hline 15 & $\begin{array}{l}\text { Ohara K, et al. Chest wall deformities and thoracic scoliosis after costal cartilage graft harvesting. } \\
\text { Plast Reconstr Surg 1997;99(4):1030-1036. }\end{array}$ & Japan & 110 & 4.78 \\
\hline 16 & Fonkalsrud EW. Current management of pectus excavatum. World J Surg 2003;27(5): 502-508. & USA & 110 & 6.47 \\
\hline 17 & $\begin{array}{l}\text { Fonkalsrud EW, et al. Repair of pectus excavatum deformities: } 30 \text { years of experience with } 375 \\
\text { patients. Ann Surg 2000;231(3):443. }\end{array}$ & USA & 108 & 5.40 \\
\hline 18 & $\begin{array}{l}\text { Kelly RE, et al. Surgical repair of pectus excavatum markedly improves body image and perceived } \\
\text { ability for physical activity: multicenter study. Pediatrics 2008;122(6):1218-1222. }\end{array}$ & USA & 107 & 8.91 \\
\hline 19 & $\begin{array}{l}\text { Kelly Jr RE, et al. Prospective multicenter study of surgical correction of pectus excavatum: design, } \\
\text { perioperative complications, pain, and baseline pulmonary function facilitated by internet-based } \\
\text { data collection. J Am Coll Surg 2007;205(2):205-216. }\end{array}$ & USA & 107 & 8.23 \\
\hline 20 & $\begin{array}{l}\text { Haller Jr JA, et al. Evolving management of pectus excavatum based on a single institutional } \\
\text { experience of } 664 \text { patients. Ann Surg 1989;209(5):578. }\end{array}$ & USA & 104 & 3.35 \\
\hline 21 & $\begin{array}{l}\text { St Peter SD, et al. Is epidural anesthesia truly the best pain management strategy after minimally } \\
\text { invasive pectus excavatum repair? J Pediatr Surg 2008;43(1):79-82. }\end{array}$ & USA & 97 & 8.08 \\
\hline 22 & $\begin{array}{l}\text { Nuss D. Minimally invasive surgical repair of pectus excavatum. Semin Pediatr Surg } \\
\text { 2008;17(3):209-217. }\end{array}$ & USA & 96 & 8.00 \\
\hline 23 & $\begin{array}{l}\text { Kelly Jr RE. Pectus excavatum: historical background, clinical picture, preoperative evaluation } \\
\text { and criteria for operation. Semin Pediatr Surg 2008;17(3):181-193. }\end{array}$ & USA & 95 & 7.91 \\
\hline 24 & $\begin{array}{l}\text { Krasopoulos G, et al. Nuss procedure improves the quality of life in young male adults with pectus } \\
\text { excavatum deformity. Eur J Cardiothorac Surg 2006;29(1):1-5. }\end{array}$ & UK & 91 & 6.50 \\
\hline 25 & $\begin{array}{l}\text { Jaroszewski D, et al. Current management of pectus excavatum: a review and update of therapy } \\
\text { and treatment recommendations. J Am Board Fam Med 2010;23(2):230-239. }\end{array}$ & USA & 90 & 9.00 \\
\hline
\end{tabular}




\begin{tabular}{|c|c|c|c|c|}
\hline Rank & Articles & Country & $\begin{array}{l}\text { Number of } \\
\text { citation }\end{array}$ & $\begin{array}{l}\text { Citation } \\
\text { density }\end{array}$ \\
\hline 26 & $\begin{array}{l}\text { Malek MH, et al. Ventilatory and cardiovascular responses to exercise in patients with pectus } \\
\text { excavatum. Chest 2003;124(3):870-882. }\end{array}$ & USA & 89 & 5.23 \\
\hline 27 & $\begin{array}{l}\text { Kim DH, et al. Analysis of the Nuss procedure for pectus excavatum in different age groups. Ann } \\
\text { Thorac Surg 2005;80(3):1073-1077. }\end{array}$ & South Korea & 87 & 5.80 \\
\hline 28 & $\begin{array}{l}\text { Castellani C, et al. Early complications of the Nuss procedure for pectus excavatum: a prospective } \\
\text { study. Pediatr Surg Int 2008;24(6):659-666. }\end{array}$ & Austria & 83 & 6.91 \\
\hline 29 & $\begin{array}{l}\text { Cahill JL, et al. A summary of preoperative and postoperative cardiorespiratory performance in } \\
\text { patients undergoing pectus excavatum and carinatum repair. J Pediatr Surg 1984;19(4):430-433. }\end{array}$ & USA & 83 & 2.30 \\
\hline 30 & Jeung MY, et al. Imaging of chest wall disorders. Radiographics 1999;19(3):617-637. & France & 82 & 3.90 \\
\hline 31 & Shamberger RC, et al. Surgical repair of pectus excavatum. J Pediatr Surg 1988;23(7):615-622. & USA & 82 & 2.56 \\
\hline 32 & $\begin{array}{l}\text { Moss RL, et al. Major complications after minimally invasive repair of pectus excavatum. J } \\
\text { Pediatr Surg 2001;36(1):155-158. }\end{array}$ & USA & 81 & 4.26 \\
\hline 33 & $\begin{array}{l}\text { Malek MH, et al. Pulmonary function following surgical repair of pectus excavatum: a meta- } \\
\text { analysis. Eur J Cardiothorac Surg 2006;30(4):637-643. }\end{array}$ & USA & 76 & 5.42 \\
\hline 34 & $\begin{array}{l}\text { Lawson ML, et al. Impact of pectus excavatum on pulmonary function before and after repair with } \\
\text { the Nuss procedure. J Pediatr Surg 2005;40(1):174-180. }\end{array}$ & USA & 75 & 5.00 \\
\hline 35 & $\begin{array}{l}\text { Quigley PM, et al. Cardiorespiratory function before and after corrective surgery in pectus } \\
\text { excavatum. J Pediatr 1996;128(5):638-643. }\end{array}$ & USA & 75 & 3.12 \\
\hline 36 & $\begin{array}{l}\text { Engum S, et al. Is the grass greener? Early results of the Nuss Pprocedure. J Pediatr Surg } \\
2000 ; 35(2): 246-251 .\end{array}$ & USA & 73 & 3.65 \\
\hline 37 & $\begin{array}{l}\text { Hosie S, et al. Minimally invasive repair of pectus excavatum-the Nuss procedure. A European } \\
\text { multicentre experience. Eur J Pediatr Surg 2002;12(04):235-238. }\end{array}$ & Germany & 71 & 3.94 \\
\hline 38 & $\begin{array}{l}\text { Sigalet DL, et al. Cardiopulmonary effects of closed repair of pectus excavatum. J Pediatr Surg } \\
\text { 2003;38(3):380-385. }\end{array}$ & Canada & 69 & 4.05 \\
\hline 39 & $\begin{array}{l}\text { Park HJ, et al. Minimally invasive repair of pectus excavatum: a novel morphology-tailored, } \\
\text { patient-specific approach. J Thorac Cardiovasc Surg 2010;139(2):379-386. }\end{array}$ & South Korea & 67 & 6.70 \\
\hline 40 & $\begin{array}{l}\text { Miller KA, et al. Minimally invasive repair of pectus excavatum: a single institution's experience. } \\
\text { Surgery 2001;130(4):652-659. }\end{array}$ & USA & 67 & 3.52 \\
\hline 41 & $\begin{array}{l}\text { Lawson ML, et al. A pilot study of the impact of surgical repair on disease-specific quality of life } \\
\text { among patients with pectus excavatum. J Pediatr Surg 2003;38(6):916-918. }\end{array}$ & USA & 67 & 3.94 \\
\hline 42 & $\begin{array}{l}\text { Peterson RJ, et al. Noninvasive assessment of exercise cardiac function before and after pectus } \\
\text { excavatum repair. J Thorac Cardiovasc Surg 1985;90(2):251-260. }\end{array}$ & USA & 66 & 1.88 \\
\hline 43 & $\begin{array}{l}\text { Brochhausen C, et al. Pectus excavatum: history, hypotheses and treatment options. Interact } \\
\text { Cardiovasc Thorac Surg 2012;14(6):801-806. }\end{array}$ & Germany & 64 & 8.00 \\
\hline 44 & $\begin{array}{l}\text { Lane RW, et al. Laryngomalacia: a review and case report of surgical treatment with resolution of } \\
\text { pectus excavatum. Arch Otolaryngol 1984;110(8):546-551. }\end{array}$ & USA & 64 & 1.77 \\
\hline 45 & $\begin{array}{l}\text { Hebra A, et al. A simple technique for preventing bar displacement with the Nuss repair of pectus } \\
\text { excavatum. J Pediatr Surg 2001;36(8):1266-1268. }\end{array}$ & USA & 64 & 3.36 \\
\hline 46 & $\begin{array}{l}\text { Morshuis W, et al. Pulmonary function before surgery for pectus excavatum and at long-term } \\
\text { follow-up. Chest 1994;105(6):1646-1652. }\end{array}$ & Netherlands & 63 & 2.42 \\
\hline 47 & $\begin{array}{l}\text { Creswick HA, et al. Family study of the inheritance of pectus excavatum. J Pediatr Surg } \\
\text { 2006;41(10):1699-1703. }\end{array}$ & USA & 62 & 4.42 \\
\hline 48 & $\begin{array}{l}\text { Weber T, et al. Superior postoperative pain relief with thoracic epidural analgesia versus } \\
\text { intravenous patient-controlled analgesia after minimally invasive pectus excavatum repair. J } \\
\text { Thorac Cardiovasc Surg 2007;134(4):865-870. }\end{array}$ & Austria & 62 & 4.76 \\
\hline 49 & $\begin{array}{l}\text { Nasr A, et al. Comparison of the Nuss and the Ravitch procedure for pectus excavatum repair: a } \\
\text { meta-analysis. J Pediatr Surg 2010;45(5):880-886. }\end{array}$ & Canada & 61 & 6.10 \\
\hline 50 & $\begin{array}{l}\text { Steinmann C, et al. Pectus excavatum and pectus carinatum patients suffer from lower quality of } \\
\text { life and impaired body image: a control group comparison of psychological characteristics prior } \\
\text { to surgical correction. Eur J Cardiothorac Surg 2011;40(5):1138-1145. }\end{array}$ & Germany & 59 & 6.55 \\
\hline
\end{tabular}




\begin{tabular}{|c|c|c|c|c|}
\hline Rank & Articles & Country & $\begin{array}{l}\text { Number of } \\
\text { citation }\end{array}$ & $\begin{array}{l}\text { Citation } \\
\text { density }\end{array}$ \\
\hline 51 & Shamberger RC, et al. Surgical correction of pectus carinatum. J Pediatr Surg 1987;22(1):48-53. & USA & 59 & 1.78 \\
\hline 52 & $\begin{array}{l}\text { Fonkalsrud EW, et al. Comparison of minimally invasive and modified Ravitch pectus excavatum } \\
\text { repair. J Pediatr Surg 2002;37(3):413-417. }\end{array}$ & USA & 59 & 3.27 \\
\hline 53 & $\begin{array}{l}\text { Cartoski MJ, et al. Classification of the dysmorphology of pectus excavatum. J Pediatr Surg } \\
\text { 2006;41(9):1573-1581. }\end{array}$ & USA & 57 & 4.07 \\
\hline 54 & $\begin{array}{l}\text { Haje SA, et al. Preliminary results of orthotic treatment of pectus deformities in children and } \\
\text { adolescents. J Pediatr Orthop 1992;12(6):795-800. }\end{array}$ & Brazil & 57 & 2.03 \\
\hline 55 & $\begin{array}{l}\text { Coln D, et al. Early experience with the Nuss minimally invasive correction of pectus excavatum } \\
\text { in adults. World J Surg 2002;26(10):1217-1221. }\end{array}$ & USA & 55 & 3.05 \\
\hline 56 & $\begin{array}{l}\text { Fonkalsrud EW, et al. Repair of pectus excavatum and carinatum deformities in } 116 \text { adults. Ann } \\
\text { Surg 2002;236(3):304. }\end{array}$ & USA & 55 & 3.05 \\
\hline 57 & $\begin{array}{l}\text { Davis JT, et al. Repair of the pectus deformity: results of the Ravitch approach in the current era. } \\
\text { Ann Thorac Surg 2004;78(2):421-426. }\end{array}$ & USA & 55 & 3.43 \\
\hline 58 & $\begin{array}{l}\text { Croitoru DP, et al. The minimally invasive Nuss technique for recurrent or failed pectus excavatum } \\
\text { repair in } 50 \text { patients. J Pediatr Surg 2005;40(1):181-187. }\end{array}$ & Lebanon & 55 & 3.66 \\
\hline 59 & $\begin{array}{l}\text { Leonhardt J, et al. Complications of the minimally invasive repair of pectus excavatum. J Pediatr } \\
\text { Surg 2005;40(11):7-9. }\end{array}$ & Germany & 55 & 3.66 \\
\hline 60 & $\begin{array}{l}\text { Bouchard S, et al. Catastrophic cardiac injuries encountered during the minimally invasive repair } \\
\text { of pectus excavatum. Semin Pediatr Surg 2009;18(2):66-72. }\end{array}$ & Canada & 55 & 5.00 \\
\hline 61 & $\begin{array}{l}\text { Kelly Jr RE, et al. Pectus excavatum in a 112-year autopsy series: anatomic findings and the effect } \\
\text { on survival. J Pediatr Surg 2005;40(8):1275-1278. }\end{array}$ & USA & 54 & 3.60 \\
\hline 62 & $\begin{array}{l}\text { Haller Jr JA, et al. Cardiorespiratory function is significantly improved following corrective } \\
\text { surgery for severe pectus excavatum: proposed treatment guidelines. J Cardiovasc Surg (Torino) } \\
\text { 2000;41(1):125. }\end{array}$ & USA & 54 & 2.70 \\
\hline 63 & $\begin{array}{l}\text { Weber PG, et al. Forces to be overcome in correction of pectus excavatum. J Thorac Cardiovasc } \\
\text { Surg 2006;132(6):1369-1373. }\end{array}$ & Germany & 53 & 3.78 \\
\hline 64 & $\begin{array}{l}\text { Dzielicki J, et al. Difficulties and limitations in minimally invasive repair of pectus excavatum-6 } \\
\text { years experiences with Nuss technique. Eur J Cardiothorac Surg 2006;30(5):801-804. }\end{array}$ & Poland & 53 & 3.78 \\
\hline 65 & $\begin{array}{l}\text { Kelly Jr RE, et al. Multicenter study of pectus excavatum, final report: complications, static/ } \\
\text { exercise pulmonary function, and anatomic outcomes. J Am Coll Surg 2013;217(6):1080-1089. }\end{array}$ & USA & 53 & 7.57 \\
\hline 66 & $\begin{array}{l}\text { Pilegaard HK, et al. Routine use of minimally invasive surgery for pectus excavatum in adults. Ann } \\
\text { Thorac Surg 2008;86(3):952-956. }\end{array}$ & Denmark & 52 & 4.33 \\
\hline 67 & $\begin{array}{l}\text { Shamberger RC, et al. Cardiopulmonary function in pectus excavatum. Surg Gynecol Obstet } \\
\text { 1988;166(4):383-391. }\end{array}$ & USA & 52 & 1.62 \\
\hline 68 & $\begin{array}{l}\text { Uemura S, et al. Experience in } 100 \text { cases with the Nuss procedure using a technique for } \\
\text { stabilization of the pectus bar. Pediatr Surg Int } 2003 ; 19(3): 186-189 \text {. }\end{array}$ & Japan & 52 & 2.73 \\
\hline 69 & $\begin{array}{l}\text { Martinez-Ferro M, et al. Dynamic compression system for the correction of pectus carinatum. } \\
\text { Semin Pediatr Surg 2008;17(3):194-200. }\end{array}$ & Argentina & 51 & 4.25 \\
\hline 70 & $\begin{array}{l}\text { Humphreys II GH, et al. Pectus excavatum: late results with and without operation. J Thorac } \\
\text { Cardiovasc Surg 1980;80(5):686-695. }\end{array}$ & USA & 51 & 1.27 \\
\hline 71 & $\begin{array}{l}\text { Coln E, et al. Demonstrating relief of cardiac compression with the Nuss minimally invasive } \\
\text { repair for pectus excavatum. J Pediatr Surg 2006;41(4):683-686. }\end{array}$ & USA & 51 & 3.64 \\
\hline 72 & $\begin{array}{l}\text { Lam MW, et al. Quality-of-life outcomes after surgical correction of pectus excavatum: a } \\
\text { comparison of the Ravitch and Nuss procedures. J Pediatr Surg 2008;43(5):819-825. }\end{array}$ & Canada & 50 & 4.16 \\
\hline 73 & $\begin{array}{l}\text { Malek MH, et al. Pulmonary function following surgical repair of pectus excavatum: a meta- } \\
\text { analysis. Eur J Cardiothorac Surg 2006;30(4):637-643. }\end{array}$ & USA & 50 & 3.57 \\
\hline 74 & $\begin{array}{l}\text { Sigalet DL, et al. Long term cardiopulmonary effects of closed repair of pectus excavatum. } \\
\text { Pediatr Surg Int 2007;23(5):493-497. }\end{array}$ & Canada & 50 & 3.84 \\
\hline 75 & $\begin{array}{l}\text { Peter SDS, et al. A novel measure for pectus excavatum: the correction index. J Pediatr Surg } \\
\text { 2011;46(12):2270-22703. }\end{array}$ & USA & 49 & 5.44 \\
\hline
\end{tabular}




\begin{tabular}{|c|c|c|c|c|}
\hline Rank & Articles & Country & $\begin{array}{l}\text { Number of } \\
\text { citation }\end{array}$ & $\begin{array}{l}\text { Citation } \\
\text { density }\end{array}$ \\
\hline 76 & $\begin{array}{l}\text { Hoel TN, et al. A life-threatening complication of the Nuss-procedure for pectus excavatum. Ann } \\
\text { Thorac Surg 2006;81(1):370-372. }\end{array}$ & Norway & 49 & 3.50 \\
\hline 77 & $\begin{array}{l}\text { Schalamon J, et al. Minimally invasive correction of pectus excavatum in adult patients. J Thorac } \\
\text { Cardiovasc Surg 2006;132(3):524-529. }\end{array}$ & Austria & 49 & 3.50 \\
\hline 78 & $\begin{array}{l}\text { Maagaard M, et al. Normalized cardiopulmonary exercise function in patients with pectus } \\
\text { excavatum three years after operation. Ann Thorac Surg 2013;96(1):272-278. }\end{array}$ & Denmark & 48 & 6.85 \\
\hline 79 & $\begin{array}{l}\text { Morshuis WJ, et al. Exercise cardiorespiratory function before and one year after operation for } \\
\text { pectus excavatum. J Thorac Cardiovasc Surg 1994;107(6):1403-1409. }\end{array}$ & Netherlands & 48 & 1.84 \\
\hline 80 & $\begin{array}{l}\text { Schier F, et al. The vacuum chest wall lifter: an innovative, nonsurgical addition to the management } \\
\text { of pectus excavatum. J Pediatr Surg 2005;40(3):496-500. }\end{array}$ & Germany & 48 & 3.20 \\
\hline 81 & $\begin{array}{l}\text { Rushing GD, et al. When it is not an infection: metal allergy after the Nuss procedure for repair of } \\
\text { pectus excavatum. J Pediatr Surg 2007;42(1):93-97. }\end{array}$ & USA & 47 & 3.61 \\
\hline 82 & $\begin{array}{l}\text { Kaguraoka } \mathrm{H} \text {, et al. Degree of severity of pectus excavatum and pulmonary function in } \\
\text { preoperative and postoperative periods. J Thorac Cardiovasc Surg 1992;104(5):1483-1488. }\end{array}$ & Japan & 47 & 1.67 \\
\hline 83 & $\begin{array}{l}\text { Tuggey JM, et al. Randomised crossover study of pressure and volume non-invasive ventilation in } \\
\text { chest wall deformity. Thorax 2005;60(10):859-864. }\end{array}$ & UK & 47 & 3.13 \\
\hline 84 & $\begin{array}{l}\text { Jaroszewski DE, et al. Repair of pectus chest deformities in } 320 \text { adult patients: } 21 \text { year experience. } \\
\text { Ann Thorac Surg 2007;84(2):429-433. }\end{array}$ & USA & 47 & 3.61 \\
\hline 85 & $\begin{array}{l}\text { Gips H, et al. Cardiac perforation by a pectus bar after surgical correction of pectus excavatum: } \\
\text { case report and review of the literature. Pediatr Surg Int 2008;24(5):617-620. }\end{array}$ & Israel & 46 & 3.83 \\
\hline 86 & $\begin{array}{l}\text { Feng J, et al. The biomechanical, morphologic, and histochemical properties of the costal } \\
\text { cartilages in children with pectus excavatum. J Pediatr Surg 2001;36(12):1770-1776. }\end{array}$ & China & 46 & 2.42 \\
\hline 87 & Frey AS, et al. Nonoperative management of pectus carinatum. J Pediatr Surg 2006;41(1):40-45. & USA & 46 & 3.28 \\
\hline 88 & $\begin{array}{l}\text { Bach JR, et al. Prevention of pectus excavatum for children with spinal muscular atrophy type } 1 . \\
\text { Am J Phys Med Rehabil 2003;82(10):815-819. }\end{array}$ & USA & 46 & 2.70 \\
\hline 89 & $\begin{array}{l}\text { Tsirikos AI, et al. Congenital anomalies of the ribs and chest wall associated with congenital } \\
\text { deformities of the spine. JBJS 2005;87(11):2523-2536. }\end{array}$ & UK & 45 & 3.00 \\
\hline 90 & $\begin{array}{l}\text { Vanamo K, et al. Chest wall and spinal deformities in adults with congenital diaphragmatic } \\
\text { defects. J Pediatr Surg 1996;31(6):851-854. }\end{array}$ & Finland & 45 & 1.87 \\
\hline 91 & $\begin{array}{l}\text { Roberts J, et al. Quality of life of patients who have undergone the Nuss procedure for pectus } \\
\text { excavatum: preliminary findings. J Pediatr Surg 2003;38(5):779-783. }\end{array}$ & Canada & 45 & 2.64 \\
\hline 92 & $\begin{array}{l}\text { Butkovic D, et al. Postoperative analgesia with intravenous fentanyl PCA vs epidural block after } \\
\text { thoracoscopic pectus excavatum repair in children. Br J Anaesth 2007;98(5):677-681. }\end{array}$ & Croatia & 45 & 3.46 \\
\hline 93 & $\begin{array}{l}\text { Mansour KA, et al. Thirty-year experience with repair of pectus deformities in adults. Ann } \\
\text { Thorac Surg 2003;76(2):391-395. }\end{array}$ & Georgia & 45 & 2.64 \\
\hline 94 & $\begin{array}{l}\text { Kotzot D, et al. Etiology of chest wall deformities-a genetic review for the treating physician. J } \\
\text { Pediatr Surg 2009;44(10):2004-2011. }\end{array}$ & Austria & 44 & 4.00 \\
\hline 95 & $\begin{array}{l}\text { Chetcuti P, et al. Chest wall deformity in patients with repaired esophageal atresia. J Pediatr Surg } \\
1989 ; 24(3): 244-247 .\end{array}$ & Australia & 44 & 1.41 \\
\hline 96 & $\begin{array}{l}\text { Willekes CL, et al. A 26-year review of pectus deformity repairs, including simultaneous } \\
\text { intracardiac repair. Ann Thorac Surg 1999;67(2):511-518. }\end{array}$ & USA & 44 & 2.09 \\
\hline 97 & $\begin{array}{l}\text { Abramson H, et al. A 5-year experience with a minimally invasive technique for pectus carinatum } \\
\text { repair. J Pediatr Surg 2009;44(1):118-124. }\end{array}$ & Argentina & 43 & 3.90 \\
\hline 98 & $\begin{array}{l}\text { Einsiedel E, et al. Funnel chest. Psychological and psychosomatic aspects in children, youngsters, } \\
\text { and young adults. J Cardiovasc Surg (Torino) 1999;40(5):733-736. }\end{array}$ & Germany & 43 & 2.04 \\
\hline 99 & $\begin{array}{l}\text { Park HJ, et al. Mechanism of bar displacement and corresponding bar fixation techniques in } \\
\text { minimally invasive repair of pectus excavatum. J Pediatr Surg 2008;43(1):74-78. }\end{array}$ & South Korea & 43 & 3.58 \\
\hline 100 & $\begin{array}{l}\text { Fonkalsrud EW, et al. Force required to elevate the sternum of pectus excavatum patients. J Am } \\
\text { Coll Surg 2002;195(4):575-577. }\end{array}$ & USA & 43 & 2.38 \\
\hline
\end{tabular}


Table 2. Impact factors and citation numbers of top 10 journals

\begin{tabular}{lccc}
\hline Journal & Paper numbers & Impact factors & Citation numbers \\
\hline Journal of Pediatric Surgery & 36 & 2,092 & 3,362 \\
Annals of Thoracic Surgery & 10 & 3,919 & 698 \\
Journal of Bone and Joint Surgery-American Volume & 3 & 4,301 & 533 \\
Journal of Thoracic and Cardiovascular Surgery & 8 & 5,261 & 443 \\
Annals of Surgery & 4 & 9,476 & 430 \\
Seminars in Pediatric Surgery & 4 & 2,462 & 297 \\
Journal of The American College of Surgeons & 4 & 4,450 & 255 \\
(Surgery, Gynecology \& Obstetrics) & & & 253 \\
European Journal of Cardio-Thoracic Surgery & 4 & 3,847 & 231 \\
Pediatric Surgery International & 4 & 1,397 & 228 \\
Chest & 3 & 9,657 & \\
\hline
\end{tabular}

When the articles were sorted by decades, most articles $(n=68)$ in the top 100 were published between 2000 and 2009 (Figure 1). Years with more than three articles published were examined, and 2006 ranked the first $(n=11)$ (Figure 2). The average number of citations for those 11 articles from 2006 was 57.9 (46-91).

\section{Authors and countries}

Kelly was the principal author having the highest number of articles with six. The principal author with the most citations per article was Nuss with 285 . The highest numbers of cited publications by country were from the United States ( $n=55)$, Germany $(n=7)$, Canada $(n=6)$, and South Korea $(n=5)$ (Figure 3).

\section{Subject}

The most discussed topic, with 3,304 citations in 35 articles, was experience transfer regarding results of surgical techniques (Nuss and Ravitch procedures and modifications). In the second place, 10 articles with 786 citations discussed complications following pectus deformity surgery (Table 3 ).

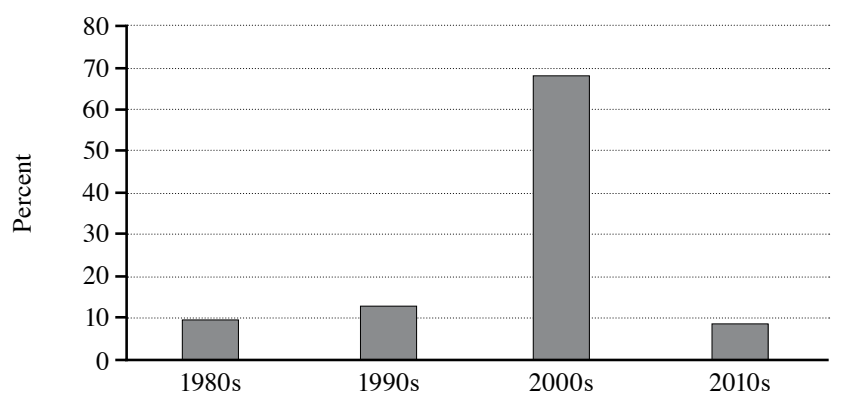

Figure 1. Articles sorted by decades.
Technical details and experience transfer related to a surgical technique showed an increasing trend over the last two decades. The articles related to the complications of surgery started to receive high citations after 2000s. Studies on cardiopulmonary functions were found to be highly cited in every period (Table 4).

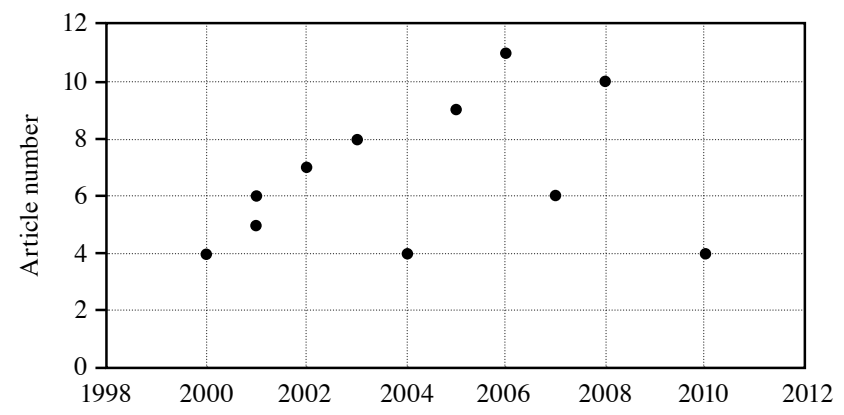

Figure 2. Years with more than three articles published.

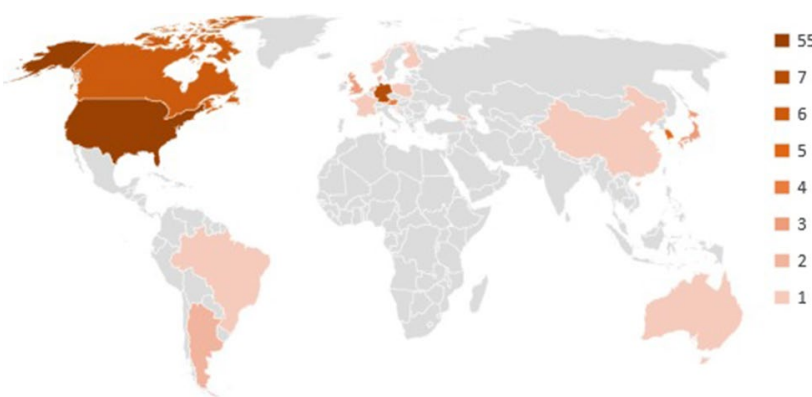

Figure 3. World map of top 100 most-cited articles. 
Table 3. Number of article and citation according to top 10 subject

\begin{tabular}{lcc}
\hline Subject & Number of article & Number of citation \\
\hline Experience on 1-surgical-technique & 35 & 3,304 \\
Complications & 10 & 786 \\
Coexisting anomalies & 6 & 783 \\
Others (Indexing, Radiologic assessment, Prevention, etc.) & 6 & 642 \\
Cardiopulmonary function & 8 & 479 \\
Pulmonary function & 6 & 453 \\
Life quality, psychosocial analysis & 6 & 412 \\
2-technique comparison & 4 & 319 \\
Pain control & 3 & 204 \\
Pectus carinatum & 4 & 199 \\
\hline
\end{tabular}

\section{Types of articles}

The article types were classified as 82 original articles (48 retrospective articles, 34 prospective articles), eight review articles, seven case reports, and three meta-analyses.

There was no statistically significant relationship between the impact factor and the number of articles, the number of citations, and the average number of citations ( $\mathrm{p}=0.965, \mathrm{p}=0.571$, and $\mathrm{p}=0.372$, respectively) (Table 5). However, there was a strong positive correlation $(\mathrm{r}=0.886)$ between the number of articles in a journal and the number of citations, which was statistically significant $(p<0.001)$. As the number of published articles increased, the number of citations increased accordingly (Table 6, Figure 4).

Table 4. Distribution of the subjects by decades

\begin{tabular}{lcccc}
\hline Subjects & $1980 \mathrm{~s}$ & $1990 \mathrm{~s}$ & $2000 \mathrm{~s}$ & $2010 \mathrm{~s}$ \\
\hline 2-technique comparison & 0 & 0 & 3 & 1 \\
Anatomical studies & 0 & 0 & 2 & 0 \\
Cardiopulmonary function & 2 & 2 & 3 & 1 \\
Cardiovascular function & 1 & 0 & 1 & 0 \\
Coexisting anomalies & 0 & 2 & 4 & 0 \\
Complications & 0 & 1 & 9 & 0 \\
Experience on 1-nonsurgical technique & 0 & 1 & 2 & 0 \\
Experience on 1-surgical technique & 3 & 2 & 25 & 5 \\
Genetics & 0 & 0 & 2 & 0 \\
Life quality, psychosocial analysis & 0 & 1 & 4 & 1 \\
Others & 2 & 1 & 2 & 1 \\
Pain control & 0 & 0 & 3 & 0 \\
PC & 1 & 0 & 3 & 0 \\
PD as a complication & 1 & 1 & 0 & 0 \\
PE and PC & 0 & 0 & 1 & 0 \\
Pulmonary function & 0 & 2 & 4 & 0 \\
\hline
\end{tabular}

PC: Pectus carinatum; PD: Pectus deformity; PE: Pectus excavatum. 
Table 5. Relationship between the impact factor and the number of articles, the number of citations, and the average number of citations $(n=27)$

\begin{tabular}{lclcc}
\hline & & $\mathrm{r}$ & $p$ \\
\hline Paper number & $*$ & Impact factors & -0.009 & 0.965 \\
Paper number & $*$ & Citation number & 0.886 & $<0.001$ \\
Impact factors & $*$ & Citation number & 0.114 & 0.571 \\
Impact factors & $*$ & Mean citation number (citation number/paper number) & 0.179 & 0.372 \\
\hline
\end{tabular}

Spearman's rho test; r: correlation coefficient.

Table 6. Correlation between the number of articles in a journal and the number of citations

\begin{tabular}{lccc}
\hline & Mean \pm SD & Median & Min-Max \\
\hline Paper number & $3.7 \pm 6.8$ & 1 & $1-36$ \\
Impact factors & $4.4 \pm 3.5$ & 3.739 & $1.062-16.49$ \\
Citation number & $307.0 \pm 632.6$ & 111 & $45-3362$ \\
Mean citation number (citation number/paper number) & $80.4 \pm 30.8$ & 74.25 & $45-177.67$ \\
\hline SD: Standard deviation. & & &
\end{tabular}

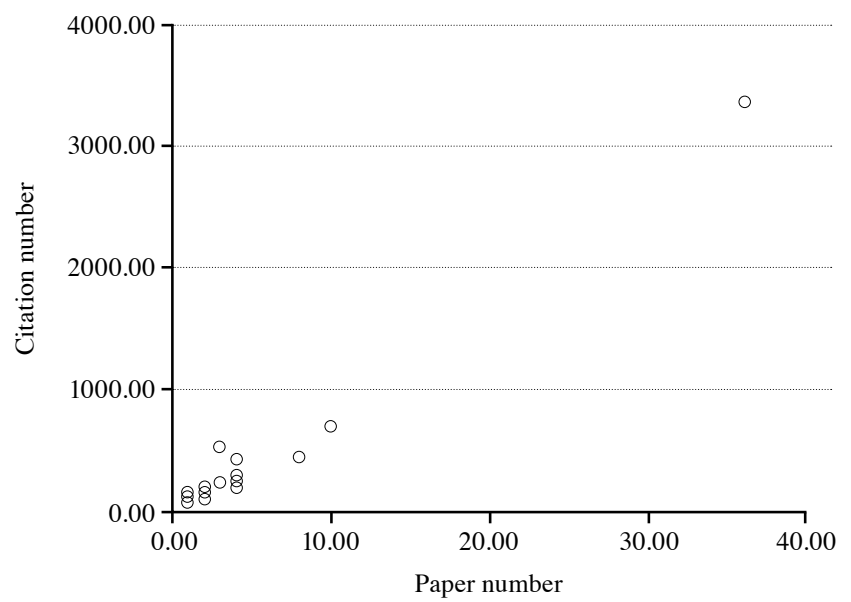

Figure 4. As the number of published articles increases, the number of citations increases accordingly.

\section{DISCUSSION}

Bibliometric analyses show what kinds of articles are published on a topic within a historical period, allowing a comprehensive understanding of the parts of a subject having global interest. In this study, we attempted to understand what were done on chest wall deformities over the years, which studies were most cited in other researches, and what was became the gold standard. We found a positive correlation between the number of articles and the number of citations in a journal, suggesting that high-value articles were consistently published. The lack of a statistical relationship between the impact factor and the number of articles in a journal proves that qualitative rather than quantitative values are reflected by the impact factor. The fact that 100 articles were published in 27 different journals by 69 different first authors from 21 countries is an indication that the interest in pectus deformities is quite extensive and meaningful. The average of the impact factors for these journals was also found to be quite high.

The number of citations objectively reflects the strength of the impact of a scientific article and is considered an academic evaluation criterion for researchers. The number of citations is known as the best criterion for analyzing the impact of a journal or of a single article; however, annual citation density is important to compare two articles in a bibliometric study. In this study, the articles ranked the first, third, and seventh in number of citations were the top three according to the citation density. Thus, we consider that the density of citations should be taken into consideration in addition to the number of citations in a bibliometric study.

The fact that 17 authors who published more than one article on the list also underscores the importance of the average number of citations per article. While Kelly authored the most articles, the author with the highest average number of citations per article was Nuss, showing that not only the number of articles should be taken into account. Of note, the Ravitch's articles, which were groundbreaking in 
pectus deformities by defining an important surgical technique and frequentlydefining it in comparison with the Nuss procedure in two-technique comparisons, as noted above, remained out of this study, as they were published long before 1975. ${ }^{[10,11]}$

Sixty-eight of the top 100 articles cited were published between 2000 and 2009. In this peak period, a "golden age" of academic studies related to pectus deformities, mainly experienced with a single surgical technique $(n=25)$, complications $(n=9)$, and cardiopulmonary function $(n=7)$ were studied and presented on the academic platform.

The articles designed prospectivelyconstitute $41.4 \%$ of the original articles, while the retrospective studies were on experience transfer in the form of larger series of cases with long follow-up.

The main limitation of this study is that only Web of Science Core Collection data and post-1975 data were evaluated.However, Web of Science is a generally accepted database that scans SCI-EXPANDED, SSCI, A \& HCI, CPCI-S, CPCI-SSH, BKCI-S, BKCI-SSH, ESCI indexes and contains the majority of the citations available.

In conclusion, bibliometric analyses play an important role in determining the non-contact points of a subject, understanding the most controversial issues, and even choosing the journal to which an article would be submitted. According to the number and density of citations, a surgical or non-surgical technique begins to be undertaken as a routine or the gold standard in practice and is the pioneer of successive articles in this regard. Our study results suggest that the studies of pectus deformities would continue and, from now on, issues such as complications and technical details would come to the forefront in the articles.

\section{Declaration of conflicting interests}

The authors declared no conflicts of interest with respect to the authorship and/or publication of this article.

\section{Funding}

The authors received no financial support for the research and/or authorship of this article.

\section{REFERENCES}

1. Bauhinus J, Schenck von Grafenberg J. Observationum medicarum, rararum, novarum, admirabilium, et monstrosarum, liber secundus. Departibus vitalibus, thorace contentis. Observation 1594;264:516.

2. Meyer L. Fur chirurgischen bedandlung der angeborenen trichterbrust. Klin Wochenschr 1922;1:647.

3. O'Sullivan KE, Kelly JC, Hurley JP. The 100 most cited publications in cardiac surgery: A bibliometric analysis. Ir J Med Sci 2015;184:91-9.

4. Ding H, Song X, Chen L, Zheng X, Jiang G. The 100 mostcited papers in general thoracic surgery: A bibliography analysis. Int J Surg 2018;53:230-8.

5. Joyce CW, Kelly JC, Sugrue C. A bibliometric analysis of the 100 most influential papers in burns. Burns 2014;40:30-7.

6. Yin X, Cheng F, Wang X, Mu J, Ma C, Zhai C, et al. Top 100 cited articles on rheumatoid arthritis: A bibliometric analysis. Medicine (Baltimore) 2019;98:e14523.

7. Nuss D, Kelly RE Jr, Croitoru DP, Katz ME. A 10-year review of a minimally invasive technique for the correction of pectus excavatum. J Pediatr Surg 1998;33:545-52.

8. Kelly RE, Goretsky MJ, Obermeyer R, Kuhn MA, Redlinger $\mathrm{R}$, Haney TS, et al. Twenty-one years of experience with minimally invasive repair of pectus excavatum by the Nuss procedure in 1215 patients. Ann Surg 2010;252:1072-81.

9. Campbell RM Jr, Smith MD, Mayes TC, Mangos JA, WilleyCourand DB, Kose N, et al. The characteristics of thoracic insufficiency syndrome associated with fused ribs and congenital scoliosis. J Bone Joint Surg Am 2003;85:399-408.

10. Ravitch MM. The operative treatment of pectus excavatum. Ann Surg 1949;129:429-44.

11. Ravitch MM. Operative correction of Pectus Carinatum (pigeon breast). Ann Surg 1960;151:705-14. 